\title{
NEW ADVANCED METHODS IN SIDE CRASH TESTING
}

\section{JAKUB JELÍNEK}

TÜV SÜD Czech, Novodvorská 994/138, +420606613227, jakub.jelinek@tuvsud.com

České vysoké učení technické v Praze, Fakulta strojní, Technická 4, +420606613227, jakub.jelinek@fs.cvut.cz

\section{MILAN RŮŽIČKA}

České vysoké učení technické v Praze, Fakulta strojní, Technická 4, milan.ruzicka@fs.cvut.cz

\section{ALŽBĚTA KAFKOVÁ}

TÜV SÜD Czech, Novodvorská 994/138, +420725894624, alzbeta.kafkova@tuvsud.com

České vysoké učení technické v Praze, Fakulta strojní, Technická 4, alzbeta.kafkova@fs.cvut.cz

\section{ABSTRACT}

This work follows up the previous work [1] regarding the used methodology in the field of passive safety, ie. crash testing. The work is based on experience gained in the Active Lateral Impact Simulator (ALIS) project and describes complete process. The main focus has been given to the fine-tuning of the boundary conditions and loading of the system in order to ensure correct biomechanical loads.

\section{KEYWORDS: CRASH TEST, FINITE ELEMENT METHOD, DESIGN OF EXPERIMENT, BIOMECHANICAL LOADS, DYCOT, ALIS}

\section{SHRNUTí}

Tato práce navazuje na předešlé příspěvky [1] týkající se metodiky v oblasti pasivní bezpečnosti, a zejména crash testování. Tento článek vychází ze zkušenosti získané v rámci projektu bočních nárazů a za použití systému Active Lateral Impact Simulator (ALIS) a popisuje celý postup. Hlavní důraz je kladen na jemné ladění počátečních podmínek a náhradního zatí̌ení pưsobícího na celý systém a $\mathrm{k}$ dosažení požadovaných biomechanických kritérií.

KLÍČOVÁ SLOVA: NÁRAZOVÁ ZKOUŠKA, METODA KONEČNÝCH PRVKŮ, NÁVRH EXPERIMENTU, BIOMECHANICKÉ ZATí̌̌ENÍ, DYCOT, ALIS

\section{INTRODUCTION}

This work proposes a new advanced approach of combined virtual and physical testing. The main idea is to reduce development time and associated costs by using sled testing which used to be used mainly for physical simulation of frontal crashes. Simulation of side crash in sled environment is not a brand-new topic, but certainly very complex one. This method is not really used on regular basis especially due to predictability issues and low accuracy. This work presents new approach of combination both virtual and physical testing. The whole process starts with full crash simulation, goes through conversion of virtual model to reduced sled model, sled testing and finally is wrapped up with full vehicle crash.

\section{MAIN SECTION}

\subsection{DYCOT}

TÜV SÜD Czech has recently invested a large sum to test lab equipped with sled system (catapult) - DYnamic COmponent Testing (DYCOT) [2]. Sled test system consists of sled with grid holes and pusher sled, where all electronics and measurement equipment is mounted as also shown on Figure 1. The pusher sled is being pushed by CSA catapult, equipped with hydraulic piston that can accelerate the sled by up to $90 \mathrm{G}$ to total velocity of $100 \mathrm{kph}$ with payload of $1000 \mathrm{~kg}$. When fully loaded (payload of $5000 \mathrm{~kg}$ ), the piston is capable of accelerating the sled up to 35G. Maximum force is equal to $2.5 \mathrm{MN}$. Maximum acceleration gradient is $14 \mathrm{G} / \mathrm{ms}$. 


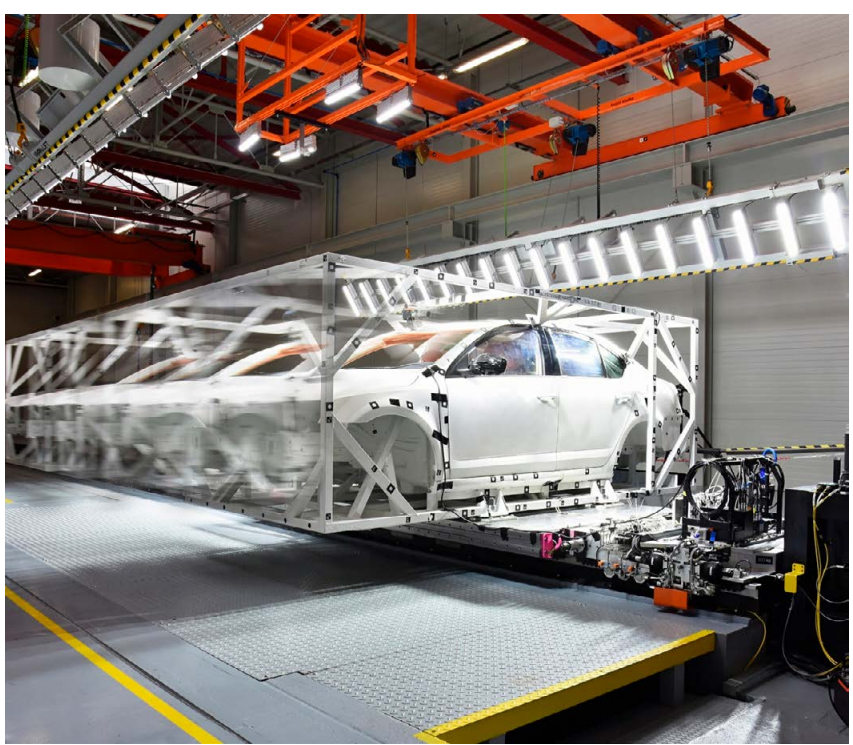

FIGURE 1: DYCOT system during the acceleration of the test sample OBRÁZEK 1: Systém DYCOT při urychlení zkušebního vzorku

It is usually used for frontal crash test where the occupant safety is being tested. It can also be used for testing of crash-landing of any small airplane that would fit in the lab. Latest addition to the service portfolio is battery pack testing for any battery packs up to $1000 \mathrm{~kg}$.

\subsection{ALIS}

The capabilities of DYCOT sled system have been significantly increased by adding ALIS into serie, right next to the sled platform see Figure 2. It uses up to 6 hydraulic cylinders in order to correctly simulate the door intrusion kinematics during the side crash. It enables one to use only small part of the car together with dummies and restraint systems and carry out simulation of the side crash with focus on restraint system and biomechanical loads.

The system may seem as a "train of trolleys". The driven sled trolley is mounted to the main hydraulic system that generates the main acceleration pulse. ALIS is mounted on the separate trolley, attached to the sled. The whole structure is shown on Figure 3, where main components are identified. The lateral system consists of additional pneumatic system directly attached to several pneumatic cylinders, ALIS primary structure and control system, linear guiding system and "impact break-in structure".

The main reason for testing is to fine-tune the restraint system in order to get the best biomechanical loading in cheaper and quicker way - on sled. The fact that sled tests with only several trim parts and seats are used instead of fully equipped crash vehicles makes this approach very effective. We are definitely talking about tens of percents.

Door structure deforms and biomechanical loads are reached

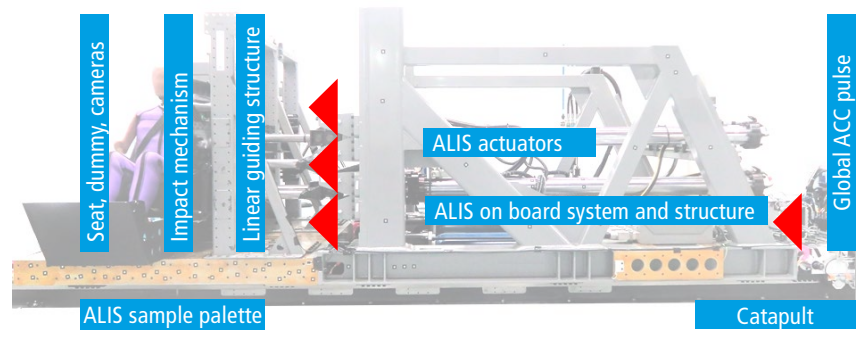

FIGURE 3: DYCOT + ALIS concept

OBRÁZEK 3: Koncept DYCOT + ALIS

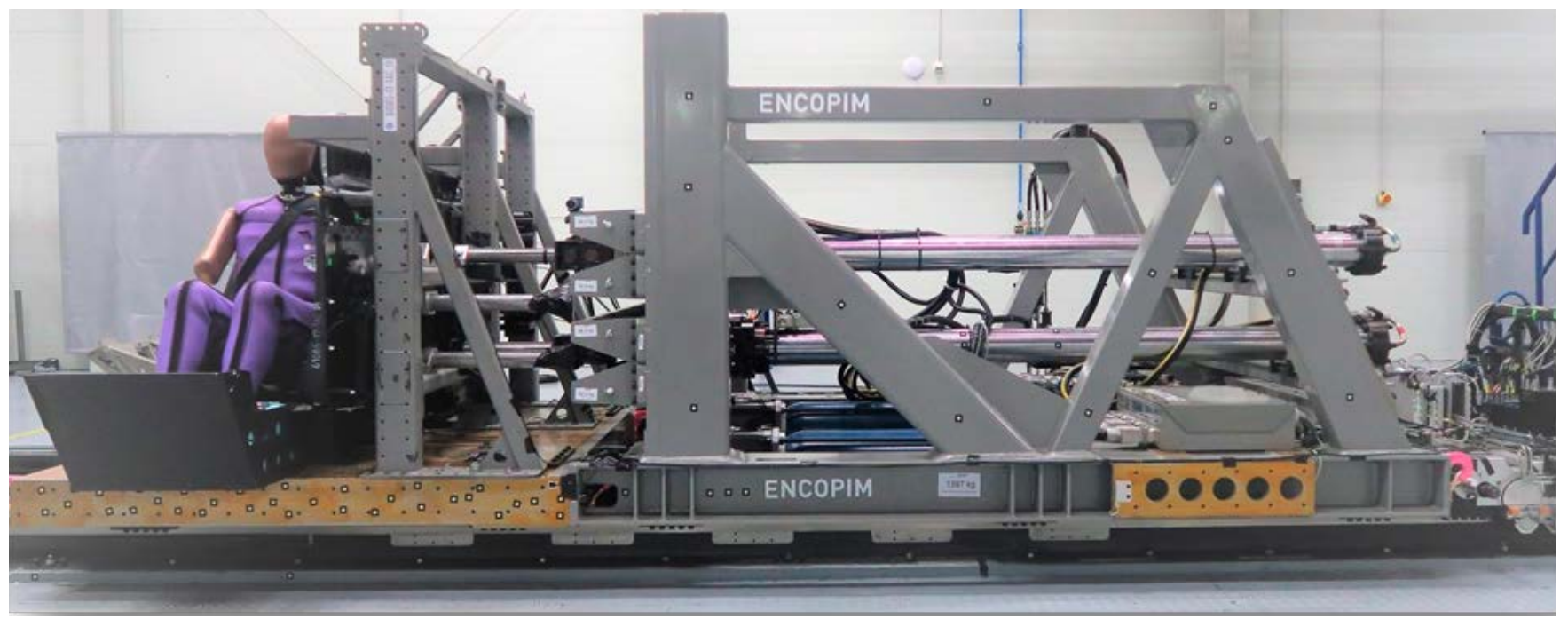

FIGURE 2: Active Lateral Intrusion Simulator (ALIS)

OBRÁZEK 2: Active Lateral Intrusion Simulator (ALIS) 


\subsection{METHODOLOGY}

The whole process starts with $\mathrm{FE}$ simulation of full vehicle crash and is shown in Appendix A. It is also very important to mention that usually testing consists of two sets of tests. The first one inputs are based on virtual model and results only and gets the initial recommendations for the first crash test. The second loop inputs are already based on this crash test and requires further development and tuning of ALIS.

\subsection{DESIGN OF EXPERIMENT (DOE) [3]}

The main objective is to develop a virtual method that would allow reducing full crash into sled crash via ALIS, defining complete ALIS setup and give highly accurate results, while reducing costs.

The DoE method is advanced mathematical method that uses n-dimensional mathematical surface for response values prediction based on combination of input parameters. The aim is to get ideally perfect match between full crash model as given at the beginning of the project and ALIS reduced model.

Amount of input parameters is very often high. One of the ways how to put up with them might be Design of Experiment (DoE) with response surface creation or "step-by-step" iteration with subsequent physical validation as shown in Figure 4. Such method would reduce number of runs and predicts multiple results based on input parameter combinations. Such pulses have to fulfill feasibility criteria of the cylinders and catapult.

\subsubsection{PULSE TUNING PROCEDURE}

There are several pulses that come into the whole simulation and subsequent physical test. In order to identify and tune pulses two main steps have been chosen. Firstly, contribution of every pulse needs to be determined and secondly chosen pulses have to be fine-tuned in a special manner that will ensure both physical feasibility and biomechanical responses.
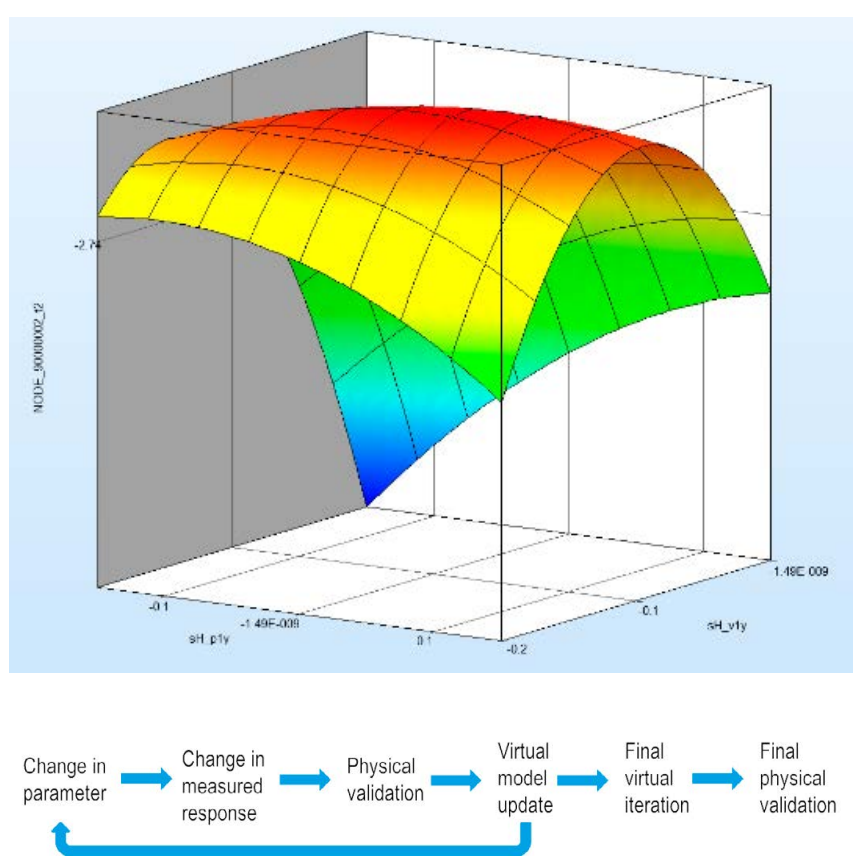

FIGURE 4: DoE response surface (top), step-by-step process (bottom) OBRÁZEK 4: DoE povrch (nahoře), postupný proces ALIS řešení (dole)

\subsubsection{PULSE IDENTIFICATION}

Currently there are three hydraulic cylinders available at the ALIS system. One is $120 \mathrm{kN}$ and other two are $60 \mathrm{kN}$ and therefore three pulses are available. Additional pulse comes from the catapult that represents overall pulses during the side crash. That makes it four pulses available for the first stage of DoE testing. Each pulse has got several parameters such as scale factor for both abscissa and ordinate and also offset values for both abscissa and ordinate. All four pulses have following set of parameters as shown in Figure 5.

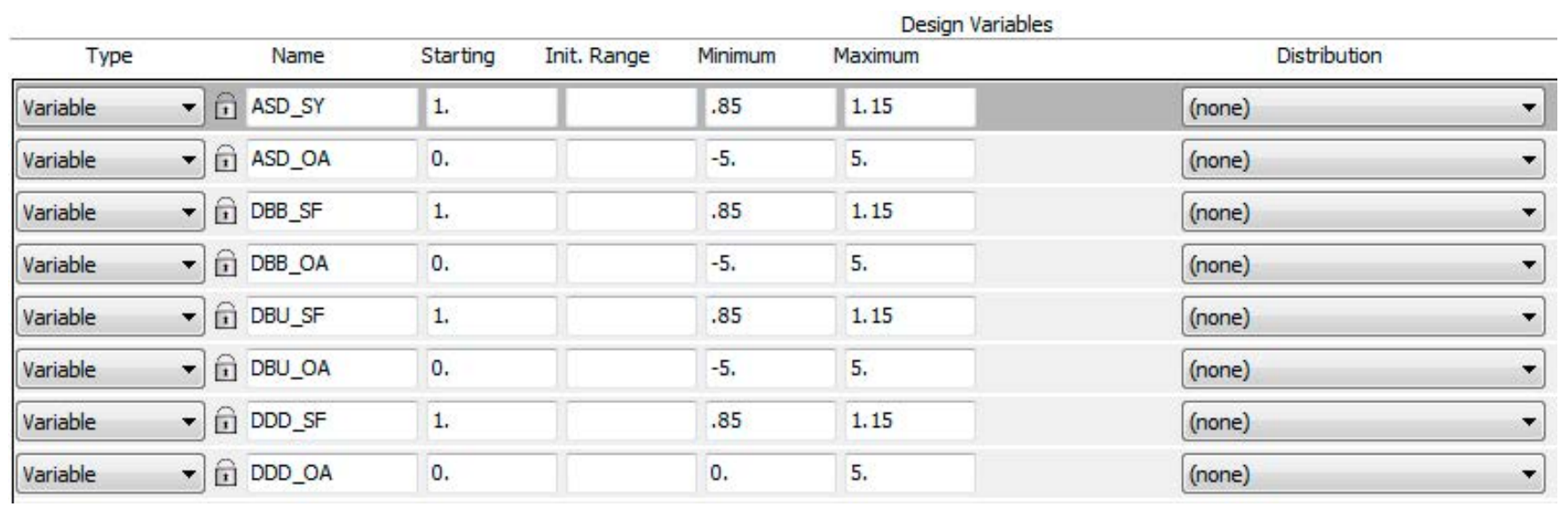

FIGURE 5: List of design variables OBRÁZEK 5: Seznam vstupních proměnných 
Following variable abbreviations are used:

- ASD_SY - scale factor of sled

- ASD_OA - pulse offset of sled

- DBB_SF - scale factor of actuator at B-pillar bottom

- DBB_OA - pulse offset of actuator at B-pillar bottom

- DBU_SF - scale factor of actuator at B-pillar upper

- DBB_OA - pulse offset of actuator at B-pillar upper

- DDD_SF - scale factor of actuator at door structure

- DDD_OA - pulse offset of actuator at door structure
Since there are 8 variables, the resultant design space will be 8D. Since there is no simple way of illustrating the $8 \mathrm{D}$ interactions, we have to go down to 3D visualisation. When always 3 variables are selected and can be switched for any other variable.

All 200 experiments (simulations) have to be run

It has to be pointed out that as there are 8 variables, then 8-dimensional surface will be created based on the responses and hence the complete surface is so complex that cannot be displayed.

TABLE 1: List of responses

TABULKA 1: Seznam vyhodnocovaných odezev

\begin{tabular}{|c|c|c|c|c|}
\hline ID & Type & Name & Component & Units \\
\hline 90079631 & \multirow{5}{*}{ BAR } & First thorax rib & Compression & $\mathrm{mm}$ \\
\hline 90079632 & & Second thorax rib & Compression & $\mathrm{mm}$ \\
\hline 90079633 & & Third thorax rib & Compression & $\mathrm{mm}$ \\
\hline 90079634 & & First abdomen rib & Compression & $\mathrm{mm}$ \\
\hline 90079635 & & Second abdomen rib & Compression & $\mathrm{mm}$ \\
\hline 90000002 & \multirow{5}{*}{ NODE } & Head acc & Acceleration, velocity & $\mathrm{mm} \mathrm{ms}^{-2} / \mathrm{mm} \mathrm{ms}^{-1}$ \\
\hline 90015619 & & T1 Lower neck acc & Acceleration, velocity & $\mathrm{mm} \mathrm{ms}^{-2} / \mathrm{mm} \mathrm{ms}^{-1}$ \\
\hline 90021212 & & T4 first thorax acc & Acceleration, velocity & $\mathrm{mm} \mathrm{ms}^{-2} / \mathrm{mm} \mathrm{ms}^{-1}$ \\
\hline 90023825 & & T12 second abdomen acc & Acceleration, velocity & $\mathrm{mm} \mathrm{ms}^{-2} / \mathrm{mm} \mathrm{ms}^{-1}$ \\
\hline 90029764 & & Pelvis acc & Acceleration, velocity & $\mathrm{mm} \mathrm{ms}^{-2} / \mathrm{mm} \mathrm{ms}^{-1}$ \\
\hline
\end{tabular}

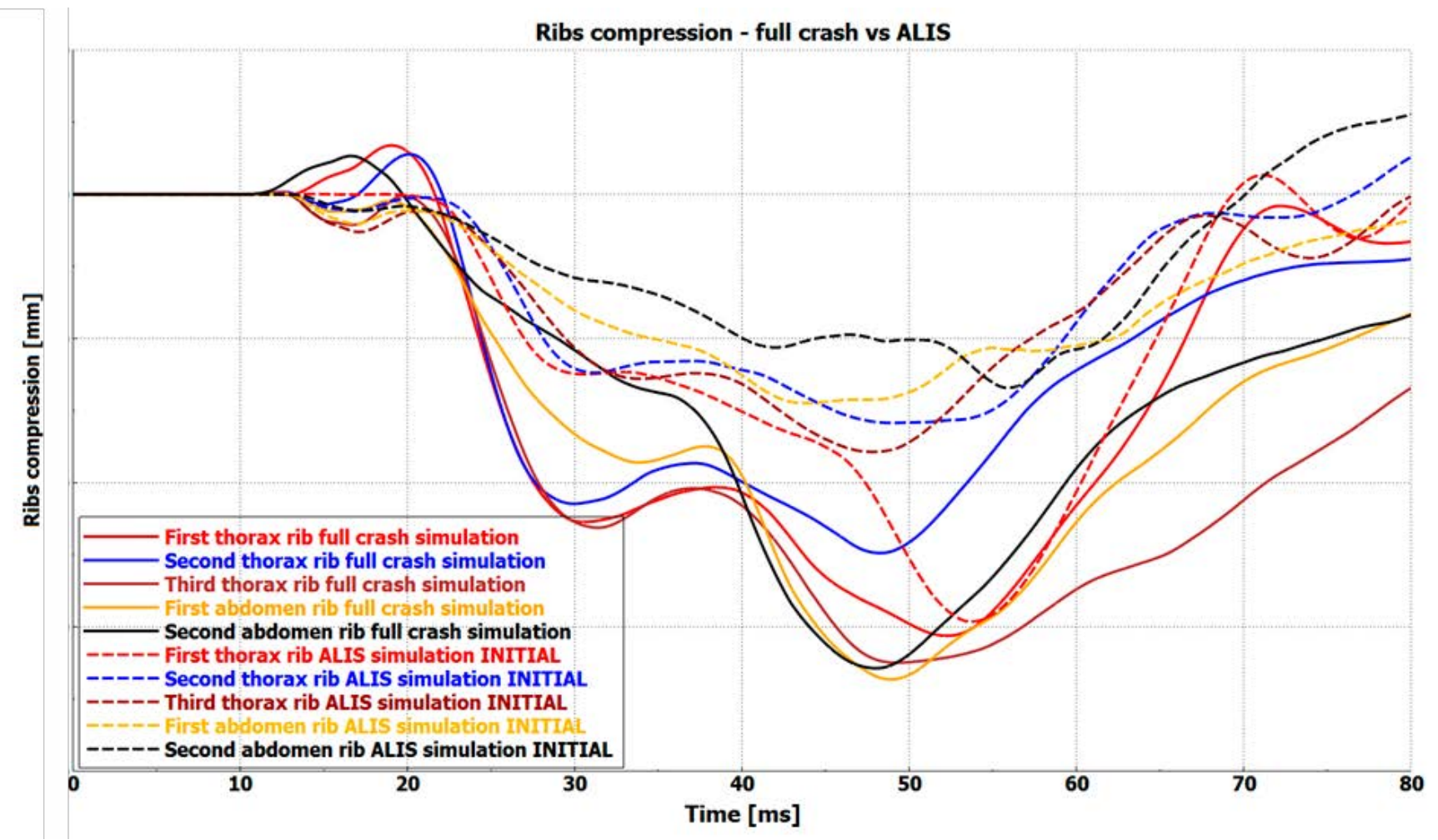

FIGURE 6: Comparison of initial ALIS vs full crash results (ribs)

OBRÁZEK 6: Porovnání úvodních výsledků ALIS s fyzickou zkouškou (žebra) 

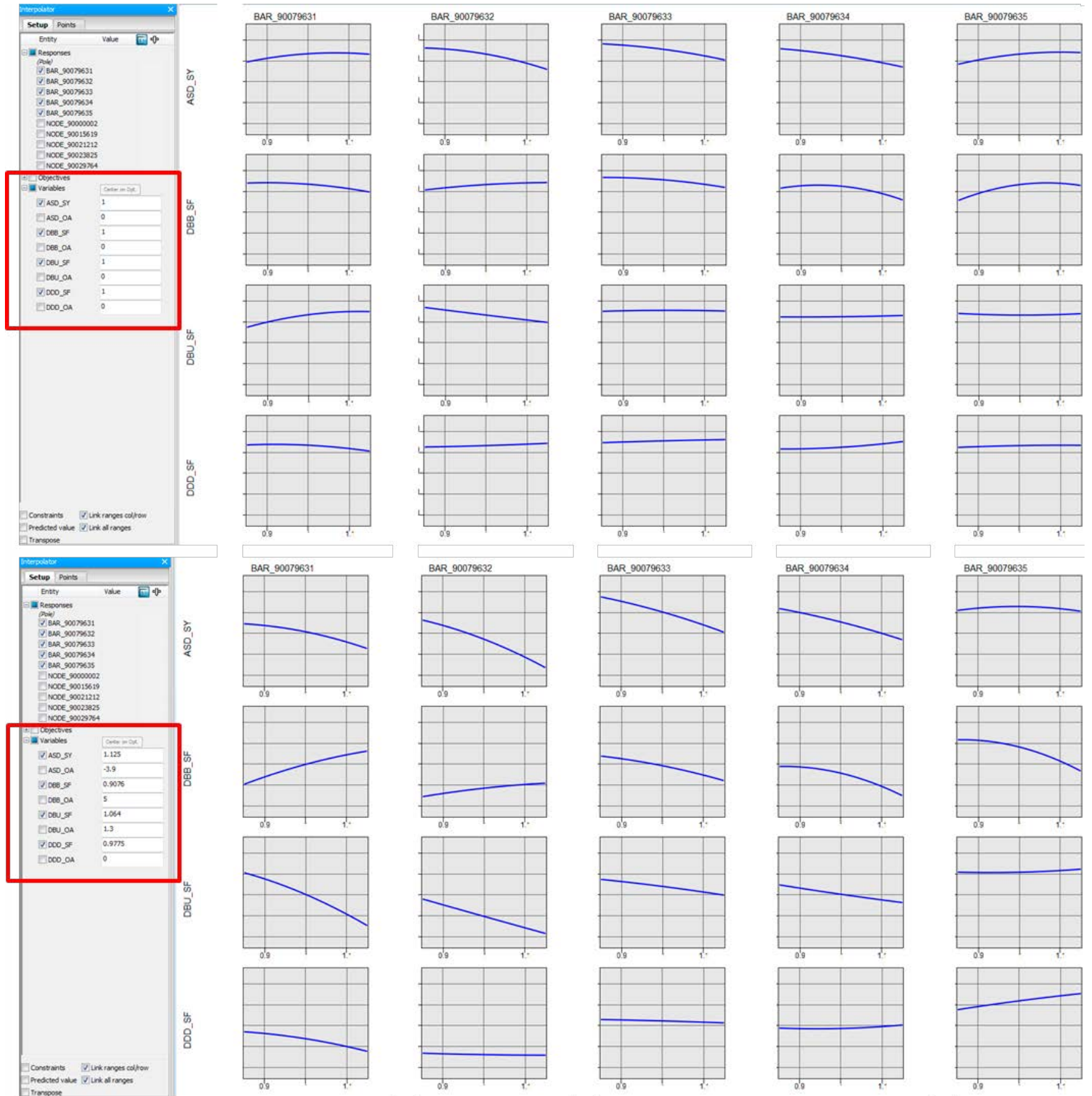

FIGURE 7: The response trends based on initial variable combination (top) and response trends based on update variable combination (bottom) OBRÁZEK 7: Trendy odezev v úvodním nastavení (nahoře) a trendy založené na upravených parametrech (dole)

\subsubsection{RESPONSES}

For response surface determination it is necessary to get responses respective to our objectives. Responses are resultants of any measurements such as force, displacement, acceleration, angle, etc. Response list is given by the scope of the sensitivity study. In all crash simulations, the most important are biomechanical loads that describes the behaviour of a human body during the crash event. The requirements differ very much from case to case so it is always unique set of criteria that are ideally to be matched. In our pole strike, it is ribs compression. Nowadays, most of the dummies and solvers are able to calculate and/or evaluate these criteria directly via sensors/points of interests. In our case several node and bars have been selected. Nodes are 


\begin{tabular}{|cccc}
\hline Label & Name & Value & Initial values \\
\hline ASD_SY & scale factor of sled & 1.02 & No \\
\hline ASD_OA & pulse offset of sled & 0 & Yes \\
\hline DBB_SF & scale factor of actuator at B-pillar bottom & 1.11 & No \\
\hline DBB_OA & pulse offset of actuator at B-pillar bottom & 0 & Yes \\
\hline DBU_SF & scale factor of actuator at B-pillar upper & 1.03 & No \\
\hline DBU_OA & pulse offset of actuator at B-pillar upper & 0 & Yes \\
\hline DDD_SF & scale factor of actuator at door structure & 0.98 & No \\
\hline DDD_OA & pulse offset of actuator at door structure & 1 & No
\end{tabular}

used for tuning of controlled trim deformation and its velocity. Simply the velocity and deformation of the trim ensures the same initial conditions as per full crash. Bar then are used for force (shoulder) and displacement (rib compression) evaluation. This metric is the most important for most of the safety crash engineers.

Responses are used for response surface modelling and results evaluation. In our case there are several responses taken into account. They have been chosen according to the requirements of the customer and also EuroNCAP. Responses that have been used are shown in Table 1.

\section{RESULTS OF THE VIRTUAL EXPERIMENTS}

So far we have been preparing ourselves for the main task. To choose suitable variables from all available sources to achieve the intended responses. Now, when the response surface has been created and validated, the selection of variable that would fit the intended values follows.

The main reason of the virtual experiments is to perform sensitivity analyses that would later give a good knowledge of the system behaviour. This is particularly useful during the physical testing, when quick response to the current behaviour and recommendation of the next steps is highly expected and

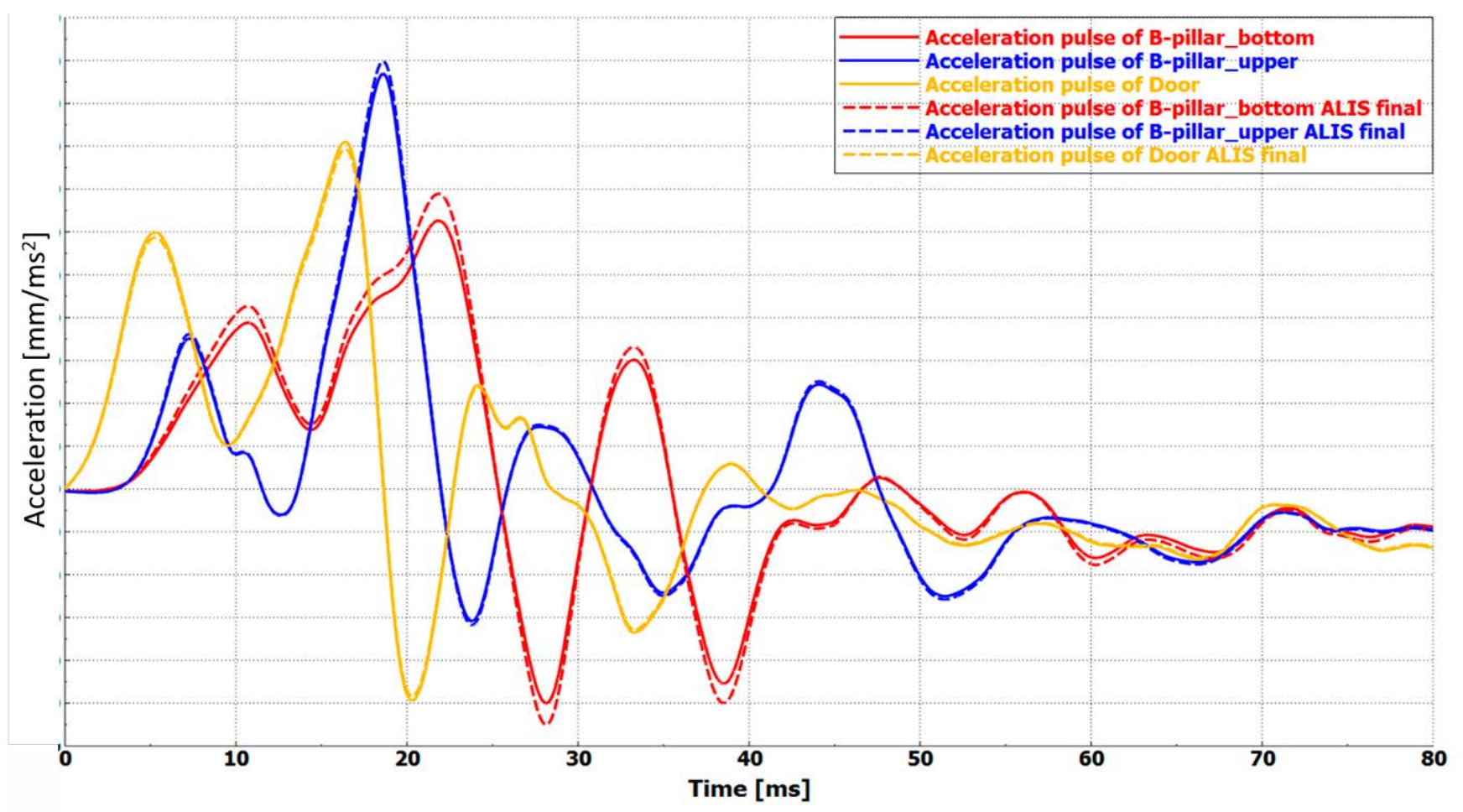

FIGURE 8: Comparison of initial and final ALIS pulses OBRÁZEK 8: Porovnání úvodních a finálních pulsů ALIS 
there is no time for further simulations. In order to get ideal pulse configurations for respective biomechanical responses, it is necessary to set the target. EuroNCAP assessment is based on scoring system of the maximal biomechanical loads.

For illustration there is a comparison of initial ALIS run, with all variables equal to 1, and full crash model shown on Figure 6.

The match is not ideal one at the moment and our goal is to get better match. Hence there has to be an update done of some or all available pulses (scale factor or offset). The suitable variable combinations can be found by user to achieve his requirements. LS-OPT can easily predict response values based when one changes the input variables as indicated on Figure 7.

This is exactly the way how to better understand mutual interaction between input variables and responses.

In our case, when the five ribs are of interest, we get desired response with following variables written in Table 2.

As these values are predicted, another testing run has to be to verify the suitability. Updated three pulses for ALIS and one for sled are shown on Figure 8.

Updated ALIS results of dummy biomechanical criteria compared to full crash data are displayed on Figure 9.

The comparison shows rather good match of both simulation approaches. Reduced model is and always will be only approximation and can only get close to the full crash simulation model. Four pulses with reasonable match, which is usually considered within deviation of $10 \%$, to the full crash model have been found and hence the first objective is complete. Secondary objective was to get a good knowledge of the system behaviour and it has also been done. It will become very useful in upcoming testing.

\section{CONCLUSION}

This paper has shown how to handle ALIS project within the virtual part. The main objective (pulses identification) has been achieved. Controlled pulses have become input parameters into the physical sled test. It is very important to get a good knowledge of the whole system behavior and how biomechanical responses are affected by variation of input as this helps the tuning procedure during early physical testing. Without it, one would not be able to recommend further steps to improve the results accuracy.

Future work is to cover the last remaining part and it is the physical testing and results validation.

\section{LIST OF NOTATIONS AND ABBREVIATIONS}

ALIS - Active Lateral Impact Simulator

ASD_SY - scale factor of sled

ASD_OA - abscissa offset

DBB_SF - B-pillar bottom scale factor

DBB_OA - B-pillar bottom abscissa offset

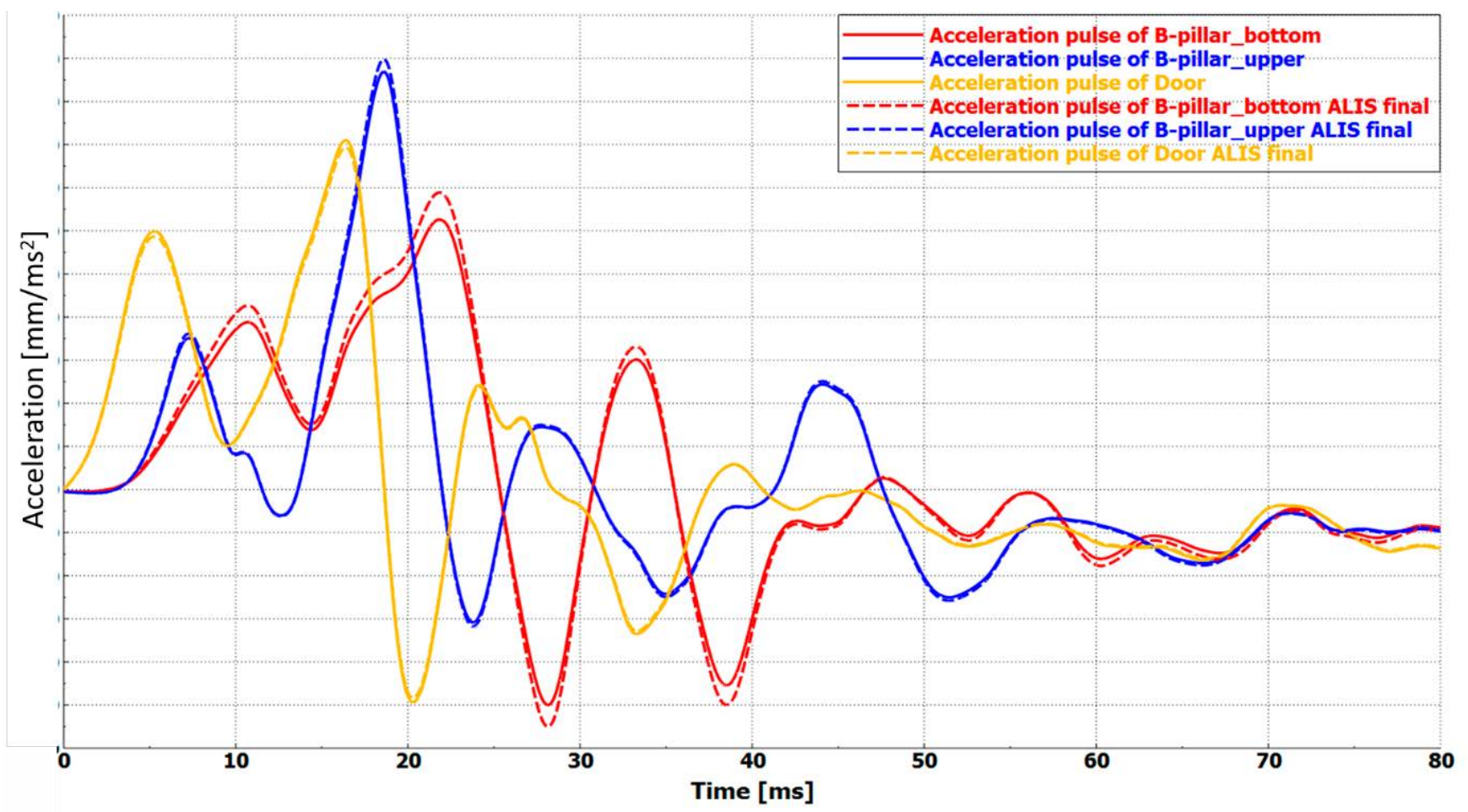

FIGURE 8: Comparison of initial and final ALIS pulses OBRÁZEK 8: Porovnání úvodních a finálních pulsů ALIS 
DBU_SF - B-pillar upper scale factor

DBU_OA - B-pillar upper abscissa offset

DDD_SF - door scale factor

DDD_OA - door abscissa offset

DoE - design of experiment

DYCOT - Dynamic Component Testing

ENCAP - European New Car Assessment Programme

\section{REFERENCES}

[1] Jelinek J., Růžička M., Kalinský M. Advanced Methods in Crash Safety Testing, 56 $6^{\text {th }}$ Conference on Experimental Stress Analysis Proceedings 2018, ISBN 978-80-270-4062-9

[2] Šotola M., 2016. DYCOT presentation, TÜV SÜD Czech, pages 3-7

[3] Jelinek J., Růžička M. Advanced methods in crash safety testing, 24 ${ }^{\text {th }}$ Workshop of Applied Mechanics 2018, ISBN 978-80-01-06453-5

\section{APPENDIX A - METHODOLOGY}

Output is to be biomechanical loads, intrusion and kinematics of important structural parts such as doors, A- and B-pillars.

Size reduction of FE model comes next. The most important outcome of this phase is determination of the ALIS settings. This includes number of cylinders used, their timing and also design of the impact structure. Amount of input parameters is countless. Other two phases are related to the physical testing.
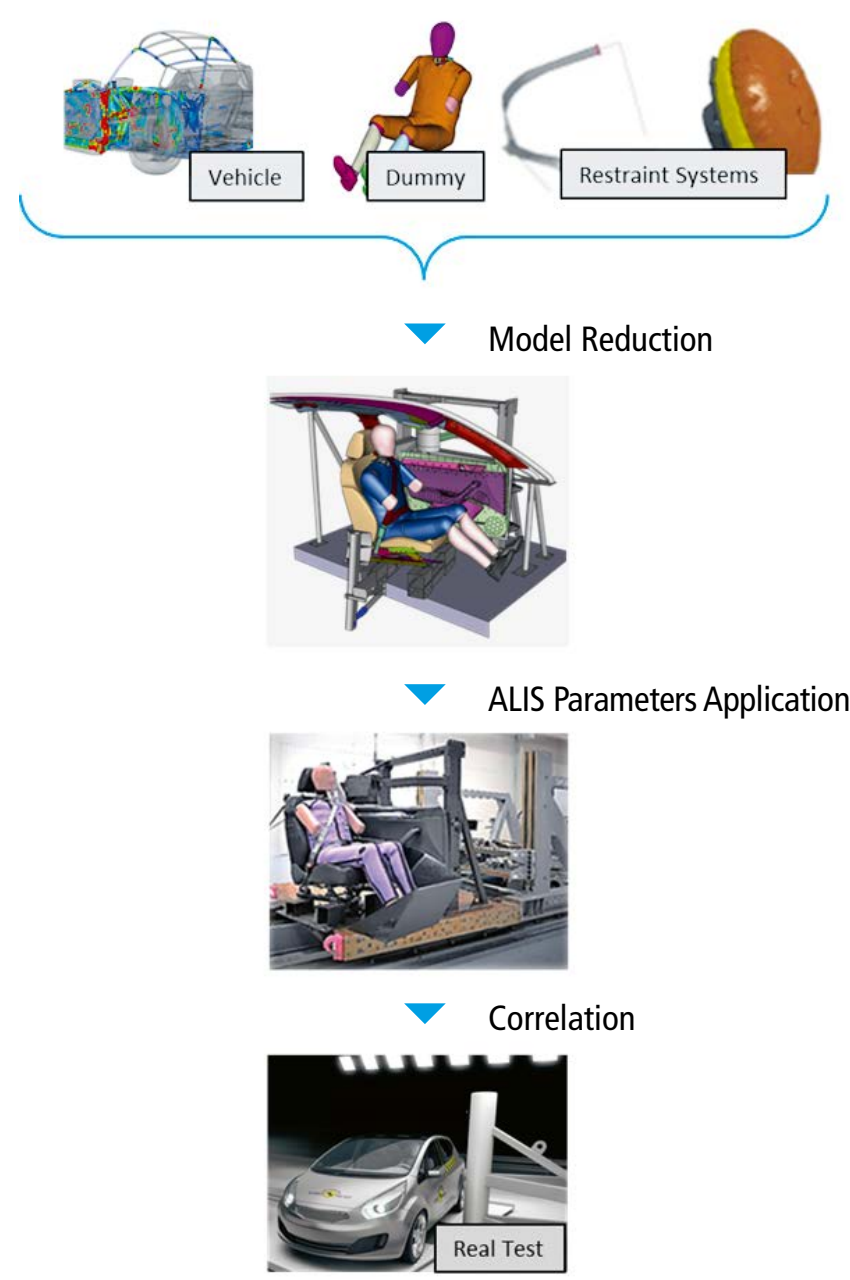

Full Car FE Simulation

Output:

Biomechanical Loads

Intrusion

Kinematics

Size-Reduced FE Simulation

Output:

Number of cylinders

Cylinder positions

Force distribution (shape and magnitude)

Impact structure design

Reduced Physical Crash Test

Output:

Biomechanical Loads

Physical Crash Test

Output:

Biomechanical Loads

FIGURE 10: Real crash to ALIS reduction procedure [3] (Courtesy of Škoda Auto)

OBRÁZEK 10: Proces redukce z reálného crash testu po ALIS [3] (S laskavým dovolením Škoda Auto) 